\title{
Lung Cancer Occurrence-Correlation with Serum Chromium Levels and Genotypes
}

\author{
Piotr Baszuk ${ }^{1}$ - Beata Janasik ${ }^{2}$ - Sandra Pietrzak ${ }^{1}$ - Wojciech Marciniak ${ }^{3}$ - Edyta Reszka ${ }^{4} \cdot$ Katarzyna Białkowska $^{1}$. \\ Ewa Jabłońska ${ }^{4}$ - Magdalena Muszyńska ${ }^{3}$ • Monika Lesicka ${ }^{4} \cdot$ Róża Derkacz $^{3}$ - Tomasz Grodzki ${ }^{5}$. Janusz Wójcik ${ }^{5}$. \\ Małgorzata Wojtyśs ${ }^{5}$. Tadeusz Dębniak ${ }^{1}$ • Cezary Cybulski ${ }^{1}$ • Jacek Gronwald ${ }^{1}$ • Bartosz Kubisa $^{5}$ • Norbert Wójcik ${ }^{5}$. \\ Jarosław Pieróg ${ }^{5}$ - Darko Gajić ${ }^{5} \cdot$ Piotr Waloszczyk $^{6} \cdot$ Rodney J. Scott $^{7,8,9} \cdot$ Wojciech Wąsowicz ${ }^{2} \cdot$ Anna Jakubowska $^{1,3}$. \\ Jan Lubiński ${ }^{1,3}$. Marcin R. Lener ${ }^{1}$ (iD
}

Received: 26 February 2020 / Accepted: 8 June 2020 / Published online: 9 July 2020

(C) The Author(s) 2020

\begin{abstract}
Lung cancer is the leading cause of cancer-related death worldwide. Exposure to environmental and occupational carcinogens is an important cause of lung cancer. One of these substances is chromium, which is found ubiquitously across the planet. The International Agency for Research on Cancer has classified chromium(VI) as a human carcinogen. The aim of this study was to assess whether serum chromium levels, as well as DNA variants in selected genes involved in carcinogenesis, xenobioticmetabolism, and oxidative stress could be helpful in the detection of lung cancer. We conducted a study using 218 lung cancer patients and 218 matched healthy controls. We measured serum chromium levels and genotyped ten genetic variants in $E R C C 2$, XRCC1, MT1B, GSTP1, ABCB1, NQ01, CRTC3, GPX1, SOD2 and CAT. The odds ratios of being diagnosed with lung cancer were calculated using conditional logistic regression with respect to serum chromium level and genotypes. The odds ratio for the occurrence of lung cancer increased with increasing serum chromium levels. The difference between the quartiles with the lowest vs. highest chromium level was more than fourfold in the entire group (OR 4.52, CI 2.17-9.42, $p<0.01$ ). This correlation was significantly increased by more than twice when specific genotypes were taken into consideration (ERCC-rs12181 TT, OR 12.34, CI 1.17-130.01, $p=0.04$; CRTC3-rs12915189 non GG, OR 9.73, CI 1.58-60.10, $p=0.01$; GSTP1-rs1695 non AA, OR 9.47, CI 2.06-43.49, $p=<0.01$; CAT-rs1001179 non CC, OR 9.18, CI 1.64-51.24, $p=0.01$ ). Total serum chromium levels $>$ $0.1 \mu \mathrm{g} / \mathrm{L}$ were correlated with $73 \%(52 / 71)$ of lung cancers diagnosed with stage I disease. Our findings support the role of chromium and the influence of key proteins on lung cancer burden in the general population.
\end{abstract}

Keywords Serum Cr level · DNA variants · Lung cancer occurrence $\cdot$ Detection marker

Electronic supplementary material The online version of this article (https://doi.org/10.1007/s12011-020-02240-6) contains supplementary material, which is available to authorized users.

Marcin R. Lener

marcinlener@poczta.onet.pl

1 Department of Genetics and Pathology, International Hereditary Cancer Center, Pomeranian Medical University in Szczecin, ul. Unii Lubelskiej 1, 71-252 Szczecin, Poland

2 Biological and Environment Monitoring Department, Nofer Institute of Occupational Medicine, ul.św. Teresy od dzieciątka Jezus 8, 91-348 Łódź, Poland

3 Read-Gene, Grzepnica, ul. Alabastrowa 8, 72-003 Grzepnica, Dobra(Szczecińska), Poland

4 Department of Molecular Genetics and Epigenetics, Nofer Institute of Occupational Medicine, ul.św. Teresy od dzieciątka Jezus 8, 91-348 Łódź, Poland
5 Department of Thoracic Surgery and Transplantation, Pomeranian Medical University in Szczecin, ul. A. Sokołowskiego 11, 70-891 Szczecin, Poland

6 Independent Laboratory of Pathology, Zdunomed, ul. Energetyków 2, 70-656 Szczecin, Poland

7 Priority Research Centre for Cancer Research, Innovation and Translation, Hunter Medical Research Institute, New Lambton Heights, Australia

8 School of Biomedical Sciences and Pharmacy, Faculty of Health and Medicine, University of Newcastle, Newcastle, Australia

9 Division of Molecular Medicine, Pathology North, John Hunter Hospital, New Lambton, NSW 2305, Australia 


\section{Introduction}

Lung cancer remains the most common cause of death among all cancers, contributing to over a million people annually succumbing to this disease worldwide. In Europe, the average 5 -year survival for patients with this cancer is estimated to be around 15\% [1]. A characteristic feature of this type of cancer is its late diagnosis when at an advanced stage due to late presentation of symptoms when treatment is no longer possible.

Therefore, it is important to improve the possibility of early detection through effective screening tests, which would result in a reduction in lung cancer mortality. Currently, diagnostic imaging of the thorax is used for early detection of lung cancer using radiological methods, liquid biopsy and, more recently, epigenetic markers.

Research on methods of early lung cancer detection by computed tomography (CT) has provided ambiguous results. In an American study on nearly 55,000 people at high risk of lung cancer it was shown that $\mathrm{CT}$ screening resulted in a reduction in mortality by $20 \%$ through the use of low-dose CT screening compared with standard chest radiography [2]. In contrast, the results of studies on Europeans with fewer numbers of people at risk of lung cancer gave inconsistent results $[3,4]$. Diagnostic imaging can often lead to the misreading of results and result in false positive of lung nodules for which malignancy could not be defined prior to surgery and pathology [4].

The liquid biopsy is another method for early detection of lung cancer. Usually a total blood sample is taken for diagnosis, prognosis, and prediction of therapeutic response [5]. Genetic markers such as circulating cell-free tumor DNA (cfDNA), e.g., TP53 mutations in the plasma cfDNA from SCLC (squamous cell lung cancer) cases; telomerase reverse transcription (TERT); exosomes; tumor-educated platelets (TEP); cell-free tumor RNA (cfRNA); plasma microRNAs (e.g. miR-1254 and miR-574-5p, miR-21, miRNA-126, miR-210, and miR-486-5p) in early-stage NSCLC (non-squamous cell lung cancer); circulating tumor cells (CTCs) [5, 6] and tumor-related antigens-p53, GBU4-5, NY-ESO-1, CAGE, Annexin 1, and SOX2 [7]. These molecular markers are all potentially valuable for prediction but lack rigorous large-scale assessment and as such are not ready for widespread use.

One of the most important examples of early detection is methylation of the p16INK $4 a$ promoter in DNA derived from bronchoalveolar lavage of resectable NSCLC [8]. Other examples include identification of smokers with the highest risk of lung cancer up to 3 years prior to clinical diagnosis due to the promoter hypermethylation of a panel of seven genes: CDKN2A, PAX5 $\beta, M G M T, D A P K$, GATA5, GATA4, and RASSF1A in sputum [9] or higher methylation frequency in NSCLC compared with normal tissues for 9 genes (APC,
CDH13, KLK10, DLEC1, RASSF1A, EFEMP1, SFRP1, $R A R-\beta$, and P16INK4A) determined by methylation profiles by MSP (methylation-specific PCR) in tissue and plasma samples [10].

The disadvantage of these methods is the high cost and the fact that they often detect lung pathologies that are not cancer. Therefore, non-invasive and inexpensive screening methods are being sought that could detect early disease in people with the highest probability of developing lung cancer.

Two important factors that influence lung risk include some heavy metals and naturally occurring genetic differences occurring in encoded proteins involved in the removal or amelioration of the effects of the heavy metal [11-13]. Carcinogenic compounds associated with lung cancer include arsenic, asbestos, beryllium, cadmium, chromium, diesel fumes (benzopyrenes), nickel and silica [14].

Exposure to $\mathrm{Cr}$ occurs primarily by inhalation in occupational settings. The International Agency for Research on Cancer (IARC) classified chromium(VI) as a carcinogen with sufficient evidence in humans for lung cancer. Except for a few reports from China, little is known about the health risks of environmental exposure to chromium [15]. Chromium is one of the elements widespread in the earth's crust. This element in small amounts is physiologically necessary by taking part in the metabolism of glucose, certain proteins and fats [16-18].

Mechanism of $\mathrm{Cr}$ carcinogenicity is unclear. There are some potential molecular mechanisms for $\mathrm{Cr}(\mathrm{VI})$-associated carcinogenicity including $\mathrm{Cr}(\mathrm{VI})$-induced oxidative stress, intracellular $\mathrm{Cr}(\mathrm{VI})$ metabolism, $\mathrm{Cr}(\mathrm{VI})$-induced DNA damage and mutagenesis, and $\mathrm{Cr}(\mathrm{VI})$-induced inflammation-all associated with tumor development [19]. $\mathrm{Cr}(\mathrm{VI})$ has been found to be highly mutagenic and penetrates into the cells and is reduced by ascorbate, NADPH, GSH [20,21], etc., which results in the formation of reactive intermediate forms $\mathrm{Cr}(\mathrm{IV})$ and $\mathrm{Cr}(\mathrm{V})$ as well as free radicals [22-24].

As a result of $\mathrm{Cr}(\mathrm{VI})$ reduction, reactive species appear, such as free radicals, superoxide anions and hydroxyl radicals, probably via a Fenton-like reaction of $\mathrm{Cr}(\mathrm{V})$ and $\mathrm{Cr}(\mathrm{IV})$ with hydrogen peroxide [25]. A study performed in human epithelial-like L-41 cells and fetal human lung fibroblasts revealed that a toxic $\mathrm{Cr}(\mathrm{VI})$ concentration $(20 \mu \mathrm{M})$ lead to an increase in ROS, and a significant reduction in catalase, glutathione, and cytosolic superoxide dismutase activity [26]. DNA damage as a result of chromium exposure is thought to be the primary mechanism of genotoxicity and mutagenicity. Among the structural genetic changes produced by $\mathrm{Cr}(\mathrm{VI})$ are: DNA adducts, DNA strand breaks, DNA-protein crosslinks, oxidized bases, abasic sites, and DNA inter- and intrastrand crosslinks [27]. Evidence suggests that chromium-DNA adducts lead to DNA double strand breaks and inhibition of their repair 
to cause chromosome instability [28-31]. Genomic instability caused by dysregulated DNA repair mechanism via chromosome instability (CIN), microsatellite instability (MIN) and abnormal cell cycle checkpoints play an important role in $\mathrm{Cr}(\mathrm{VI})$ carcinogenesis [32].

The potential role of chromate in carcinogenesis-induced epigenetic alteration is also postulated. For example, in lung cancer samples that had been exposed to chromate, $62.5 \%$ had MLH1 methylation that was correlated with MLH1 repression [33]. In addition, methylation and, consequently, reduced protein expression of the CDKN2A has been demonstrated in lung cancer [34]. Some studies hypothesize that $\mathrm{Cr}(\mathrm{VI})$ may affect global and promoter-specific histone methylation, leading to gene silencing events [35].

It has been suggested that the development of lung cancer is associated with a proinflammatory state, most often chronic pneumonia especially in non-smokers [36]. A wide range of immune responses are caused by exposure to chromium essentially inhalation of chromium particles causes damage to lung tissue and an inflammatory response in the lungs [37].

Not all $\mathrm{Cr}(\mathrm{VI})$ compounds are carcinogenic, some are cytotoxic and others genotoxic [38]. Relatively insoluble, disintegrated $\mathrm{Cr}(\mathrm{VI})$ compounds (such as zinc, lead, strontium, and sintered calcium chromate) show the greatest toxicity leading to transformation in mouse cells and the development of cancer in animals $[38,39]$. In vivo and cell culture studies have shown an increased incidence of tumor transformation and tumor formation which correlates with workers exposed to certain forms of $\mathrm{Cr}(\mathrm{VI})$ who have a significant increase in the risk of lung cancer [40, 41]. Low levels of p53 mutation, abnormal p16INK4A methylation, loss of $M L H 1$ expression and, consequently, an increase in microsatellite instability can be observed in human lung cancer cells associated with $\mathrm{Cr}(\mathrm{VI})$ exposure $[33,34,42]$.

It is well established that increased risks of cancer are associated with polymorphisms of different genes. For the studies herein, we selected polymorphisms in genes reported to be directly involved in malignant transformation and/or xenobiotic metabolism and/or oxidative stress (ERCC2, XRCC1, $M T 1 B, G S T P 1, A B C B 1, N Q 01, C R T C 3, G P X 1, S O D 2$, and $C A T)$. The selected polymorphisms characterized by relatively high frequency critical for association studies were interrogated to determine if they influenced lung cancer risk in association with $\mathrm{Cr}(\mathrm{VI})$ exposure.

Direct malignant transformation has been reported as a consequence of changes in ERCC2 and XRCC1. The single nucleotide polymorphism (SNP) rs13181 in ERCC2 involved in nucleotide excision repair (NER) and carcinogen metabolism, has been associated with lung cancer risk [43]. The results of a meta-analysis strongly implicate XRCC1 (X-Ray Repair Cross Complementing 1) in cancer development, especially rs1799782 and its association with thyroid cancer [44].
Among the genes encoding proteins involved in xenobiotic metabolism, five are of particular interest: MT1B, GSTP1, $A B C B 1, N Q 01$ and CRTC3.

The protein encoded by $M T 1 B$ gene plays a role in metal metabolism and protects cells against the toxic effects of radiation. It is also involved in the regulation of zinc and copper homeostasis, and the polymorphism rs 7191779 correlates with the risk for oral squamous cell carcinoma [45]. It was assumed that polymorphisms that change the activity of GSTP1 would be risk modifiers and markers in the development of lung cancer [46]. The rs1695 SNP in GSTP1, implicated in phase II metabolism of many substrates, including xenobiotics, is recognized as a risk factor for lung cancer [47].

$A B C B 1$ belongs to a superfamily of ATP binding cassette (ABC) transporters, and is also known as MDR1. The $A B C B 1$ polymorphism rs2032582 is associated with differential function of the protein where its potential role in toxic metal secretion or toxicity remain unexplored [48]. NQO1$\mathrm{NAD}(\mathrm{P}) \mathrm{H}$ : quinone oxidoreductase is a flavoenzyme associated with carcinogen metabolism [49]. According to a meta-analysis the NQO1 rs12915189 polymorphism is associated with lung cancer [50]. CRTC3 belongs to the family of CREB transcription coactivator genes (a protein binding the cAMP response element) [51]. The SNP rs12915189 in CRTC3 has been associated with chromium level in humans $[52,53]$.

Among the genes associated with oxidative stress, we selected polymorphisms within $G P X 1, S O D 2$, and $C A T$ genes. $G P X 1$ is a selenium-dependent enzyme that participates in the detoxification of hydrogen peroxide and a wide range of organic peroxides. It is reported that the GPXI polymorphism (Pro198Leu, rs 1050450) may contribute significantly to lung cancer risk $[54,55]$. Superoxide dismutase 2 (SOD2) belongs to the superoxide dismutase family, which can transform toxic superoxide into hydrogen peroxide and diatomic oxygen. The results of a metaanalysis strongly suggest that the rs 4880 polymorphism in SOD2 is significantly associated with the occurrence of lung cancer [56]. CAT encodes an enzyme common to all living organisms and is responsible for catalyzing the decomposition of hydrogen peroxide into water and oxygen. It was observed that reduced $C A T$ activity caused by inflammation in the lungs can lead to an intracellular increase in hydrogen peroxide and the formation of an intracellular environment suitable for DNA damage and cancer promotion [57]. A meta-analysis on the relationship between the CAT polymorphism rs1001179 and cancer risk showed a significant association with the risk of prostate cancer [58].

Our aim was to assess whether serum chromium levels, as well as DNA variants in selected genes involved in carcinogenesis, xenobiotic-metabolism, and oxidative stress could be helpful in the detection of lung cancer. 


\section{Materials and Methods}

\section{Study Group}

Two hundred eighteen patients with lung cancer participated in the study and gave informed consent. They were randomly included in this research at the Department of Thoracic Surgery in Szczecin-Zdunowo Hospital between 2012 and 2017. In all patients, lung cancer was confirmed by histopathological examination. The study was conducted in accordance with the Helsinki Declaration and with the consent of the Ethics Committee of Pomeranian Medical University in Szczecin under the number KB-0012/73/10.

Blood samples were taken from patients at the time of diagnosis but before treatment. They were then stored at $80^{\circ} \mathrm{C}$. For each lung cancer patient one unaffected individual registered at the International Hereditary Cancer Center, Pomeranian Medical University of Szczecin, was matched as a healthy control subject. Control subjects were part of a population-based study of the 1.3 million inhabitants of Poland designed to identify familial aggregations of cancer conducted by our center. All control subjects were enrolled in the study after providing written informed consent. Participants were matched for year of birth ( \pm 3 years), sex, smoking status (pack-years $\pm 20 \%$ ) and the total number of lung and other malignancies among first degree relatives. All patients were fasting at least six hours before blood sample collection. The characteristics of the individuals included in the study are shown in Table 1.

\section{Measurement of $\mathrm{Cr}$ Level}

Total serum chromium levels were measured in the Metals Analysis Laboratory, Nofer Institute of Occupational Medicine. The inductively coupled plasma mass spectroscopy (ICP-MS) technique using NexION 350D (PerkinElmer, USA) was used for sample analysis. Chromium was measured in DRC mode with ammonia (NH3, purity $>0.9999$ ) as a reaction gas for removing spectral interference.

Calibration curve standards $(0.1-10.0 \mu \mathrm{g} / \mathrm{L})$ were prepared and an external calibration method was used. The correlation coefficient of the $\mathrm{Cr}$ calibration curve was always greater than 0.999 .

The Laboratory participated in an external quality control (G-EQUAS) program to ensure accuracy, using certified/ reference standards (ClinCheck ${ }^{\circledR}$ Plasma Control, Recipe, Germany).

\section{Molecular Analyses}

Ten selected variants in ten genes were genotyped: rs 13181 in ERCC2, rs1799782 in XRCC1, rs 7191779 in MT1B, rs 1695 in GSTP1, rs2032582 in $A B C B 1$, rs1800566 in
Table 1 Characteristic of individuals for lung cancer study

\begin{tabular}{lll}
\hline Characteristics & Case $(n=218)$ & Control $(n=218)$ \\
\hline Birth year range & $1926-1966$ & $1926-1968$ \\
Age at sample, mean (range, year) & $63.93(47-87)$ & $63.59(48-86)$ \\
Sex & & \\
Male & 163 & 163 \\
Female & 55 & 55 \\
Pack-years, mean (range) & $34.52(3-135)$ & $30.43(2-100)$ \\
Smoking status & & \\
Yes & 106 & 106 \\
No & 112 & 112 \\
Stage & & \\
I & 71 & - \\
IA & 36 & - \\
IA1 & 4 & - \\
IA2 & 17 & - \\
IA3 & 15 & - \\
IB & 35 & - \\
II & 40 & - \\
IIA & 19 & - \\
IIB & 21 & - \\
III & 85 & - \\
IIIA & 45 & - \\
IIIB & 35 & - \\
IIIC & 5 & - \\
IV & 15 & - \\
IVA & 11 & - \\
IVB & 4 & - \\
Missing & 7 & \\
\hline
\end{tabular}

NQO1, rs 12915189 in CRTC3, rs 1050450 in GPX1, rs4880 in SOD2, and rs1001179 in CAT. From each individual included in the study, a $10 \mathrm{~mL}$ peripheral blood sample was collected in a vacutainer tube containing $1 \mathrm{~mL}$ of $10 \%$ sodium EDTA (EthyleneDiamineTetraacetic Acid). The genomic DNA was isolated using the detergent method [59]. SNP analyses were performed using a pre-designed Genotyping Assay $\times 40$ (Applied Biosystems). Each reaction mixture consisted of $2.5-\mu \mathrm{L}$ LightCycler 480 Probe Master Mix (Roche Diagnostics), the assay $0.125 \mu \mathrm{L}$ (Genotyping Assay $\times 40$ TaqMan, Applied Biosystems), and 1.375- $\mu \mathrm{L}$ deionized water (Roche Diagnostics). Samples were analyzed on 384-well plates. Each plate was included positive, negative and water-blind control. The genotyping data were collected and analyzed using the LightCycler 480 Instrument and the program of the LightCycler 480 Basic Software Version 1.5 (Roche Diagnostics).

\section{Statistical Analysis}

For the estimation of association of chromium levels or chromium level and genotype with lung cancer occurrence, study participants were assigned to one of four categories (quartiles) based on the chromium distribution in the entire group. The association of chromium levels with lung cancer 
occurrence was estimated by odds ratio (OR) analysis with $95 \%$ confidence intervals using univariable conditional logistic regression. The quartile with the highest amount/ratio of healthy subjects was considered the reference category for the odds ratio calculation.

All calculations were performed in the $\mathrm{R}$ statistical environment ( $\mathrm{R}$ Version 3.6.1 2019-07-05).

\section{Results}

The analysis of lung cancer occurrence based on serum chromium levels of the entire group revealed the highest frequency of cancer in the quartile with the highest chromium levels. The OR difference between the quartile with the highest and the lowest chromium levels (quartile IV vs. quartile II) was 4.52 (Table 2). Differences between subgroups of smokers and non-smokers were small-OR for the entire group did not differ more than $20 \%$ from subgroups of smokers and non-smokers (Supplementary Material Tables 1 and 2).

The above correlation was not dependent on clinical stage there were no differences between subgroups of combined stages I and II and stages III with IV (Tables 3 and 4).

When only stage I disease was compared against $\mathrm{Cr}$ levels, the OR of the lowest quartile (quartile 1) against quartile IV was 5.15 with $p=0.01$, CI $1.5-17.8$ and for quartile III OR was $8.72, p<0.01$, CI 2.6-29.8 (Table 5).

The results for all stages are available in Supplementary Material Table 3.

Inclusion of genotype data from the ten selected polymorphisms revealed an even greater correlation with disease. Several of the genotypes appeared to be associated with a significantly increased correlation with disease ( $>2$ times) between serum chromium levels and the probability of lung cancer (Table 6).

Genotypes with the strongest effect included: $E R C C 2$ rs13181TT with OR 12.34; CRTC3 rs12915189 nonGG with OR 9.73; and GSTP1 rs1695 nonAA with OR 9.474; CAT rs1001179 nonCC with OR 9.18.

The results for other genotypes are available in Supplementary Material Table 4.

Table 2 Serum chromium levels and the occurrence of lung cancer

\begin{tabular}{llllll}
\hline Quartile & Cr level $(\mu \mathrm{g} / \mathrm{L})$ & Cases & Controls & OR $(95 \% \mathrm{CI})$ & $p$-value \\
\hline I & $0.03-0.07$ & 38 & 71 & $1.23(0.60-2.52)$ & 0.58 \\
II & $0.08-0.09$ & 24 & 50 & $1.00(-)$ & - \\
III & $0.10-0.14$ & 86 & 55 & $3.97(1.98-7.94)$ & $<0.01$ \\
IV & $0.15-1.63$ & 70 & 42 & $4.52(2.17-9.42)$ & $<0.01$ \\
\hline
\end{tabular}

Italics - Results with statistical significance
Table 3 Serum chromium levels and the occurrence of stages I-II of lung cancer

\begin{tabular}{llllll}
\hline Quartile & Cr level $(\mu \mathrm{g} / \mathrm{L})$ & Cases & Controls & OR $(95 \% \mathrm{CI})$ & $p$-value \\
\hline I & $0.03-0.07$ & 15 & 38 & $1.00(-)$ & - \\
II & $0.08-0.10$ & 21 & 33 & $1.91(0.70-5.17)$ & 0.21 \\
III & $0.11-0.14$ & 37 & 16 & $6.01(2.32-15.54)$ & $<0.01$ \\
IV & $0.15-1.36$ & 38 & 24 & $5.07(1.95-13.19)$ & $<0.01$ \\
\hline
\end{tabular}

Italics - Results with statistical significance

\section{Discussion}

Lung cancer is the leading tumor for mortality worldwide [1]. The occurrence of lung cancer is affected by environmental exposure and genetic or epigenetic susceptibility to disease development and progression [60]. Important factors associated with lung cancer development are occupational exposure to carcinogens (arsenic, asbestos, beryllium, cadmium, chromium, diesel fumes, nickel, and silica) [14]. According to the European Commission, based on socioeconomic, health, and environmental impact assessment, the strongest factors related to attributable cancer deaths include $\mathrm{Cr}(\mathrm{VI})$ [61]. However, this is only an estimate on the impact of occupational exposure and not based on general population data.

The toxicity of chromium is highly dependent on its chemical form. Very high levels of serum ascorbate lead to the rapid reduction of $\mathrm{Cr}(\mathrm{VI})$ to $\mathrm{Cr}(\mathrm{III})$ thus, $\mathrm{Cr}(\mathrm{VI})$ levels in humans that have high levels of ascorbate would be expected to be low. Furthermore, $\mathrm{Cr}(\mathrm{VI})$ reduction would be expected to occur at or near the site of exposure (lung or gastrointestinal tract), which results in low circulating blood levels of $\mathrm{Cr}(\mathrm{VI})$. Taking this into account, total $\mathrm{Cr}$ levels are the appropriate measurement for this study and it is justified not to assay different $\mathrm{Cr}$ species.

In the general population, the mean levels of $\mathrm{Cr}$ in serum and urine are $0.10-0.16$ and $0.22 \mu \mathrm{g} / \mathrm{L}$, respectively [62]. The mean total chromium levels in both groups of people diagnosed with lung cancer and controls were within the limits proposed by ATSDR (Agency for Toxic Substances and Disease Registry), i.e. they do not deviate from the values considered normal for the general population. Although the

Table 4 Serum chromium levels and the occurrence of stages III-IV of lung cancer

\begin{tabular}{llllll}
\hline Quartile & Cr level $(\mu \mathrm{g} / \mathrm{L})$ & Cases & Controls & OR $(95 \% \mathrm{CI})$ & $p$-value \\
\hline I & $0.03-0.06$ & 11 & 24 & $1.00(-)$ & - \\
II & $0.07-0.09$ & 24 & 32 & $1.61(0.67-3.86)$ & 0.29 \\
III & $0.10-0.13$ & 31 & 25 & $3.05(1.22-7.63)$ & 0.02 \\
IV & $0.14-1.63$ & 34 & 19 & $4.68(1.73-12.68)$ & $<0.01$ \\
\hline
\end{tabular}

Italics - Results with statistical significance 
Table 5 Serum chromium levels and the occurrence of stage I of lung cancer

\begin{tabular}{llllll}
\hline Quartile & Cr level $(\mu \mathrm{g} / \mathrm{L})$ & Cases & Controls & OR $(95 \% \mathrm{CI})$ & $p$-value \\
\hline I & $0.03-0.07$ & 9 & 27 & $1.00(-)$ & - \\
II & $0.08-0.10$ & 10 & 17 & $2.34(0.62-8.76)$ & 0.21 \\
III & $0.11-0.15$ & 30 & 11 & $8.72(2.56-29.76)$ & $<0.01$ \\
IV & $0.16-1.36$ & 22 & 16 & $5.15(1.49-17.78)$ & 0.01 \\
\hline
\end{tabular}

Italics - Results with statistical significance

chromium levels in the group of patients with cancer are statistically significantly higher compared with those in the control group $(p<0.05)$, they were still within the normal range [62].

The data herein suggests that it may be attractive for practical purposes. We plan to measure serum chromium levels in patients from our cancer genetic outpatient clinics especially for subgroups of individuals with familial lung and/or other cancer aggregations. Patients from such families having high serum chromium levels will be provided with the option of surveillance CT scans of the lung for early disease detection. Analyses of chromium levels may be an attractive option to identify patients with early stage disease especially because the frequency of lung cancer is significantly increased (OR > $5)$ if the serum chromium level is above $0.1 \mu \mathrm{g} / \mathrm{L}$. Additionally, it is very interesting that total serum chromium levels $>0.1 \mu \mathrm{g} / \mathrm{L}$ appear to be associated with $73 \%(52 / 71)$ of lung cancer patients with stage I disease. It is well recognized that lung cancer treatment success is correlated with the clinical stage at diagnosis. De Matteis et al. studied the effect of carcinogens on the risk of lung cancer in the general population. They showed that patients appear to have an increased risk of lung cancer due to exposure to nickel-chromium (OR 1.18 ; 95\% CI 0.90-1.53), which is consistent with our study results [14]. Since smoking is one of the most important risk factors for lung cancer, we included this factor in our regression model. Differences between smoking and non-smoking subgroups were small - with the OR for the whole group not differing by more than $20 \%$ between smoking and nonsmoking groups (Supplementary Materials, Tables 1 and 2). This is in contradiction with the work of others, since it has been reported that chromium levels are much higher in smokers' lung tissues than in those of non-smokers [63].

Moreover, in our studies, we have been able to show that functional DNA variants in some genes involved in carcinogenesis, oxidative stress and xenobiotics clearance probably enhance the effects of chromium. Variants associated with an increased risk of lung cancer included ERCC2, CRTC3, GSTP1, and CAT. Generally, except for CRTC3 rs12915189, SNPs selected for this study were not recognized as affecting $\mathrm{Cr}$ levels in serum. The most likely explanation concerning these polymorphisms is that they modify the physiological response occasioned by the presence of $\mathrm{Cr}(\mathrm{VI})$. Further investigation is needed to explain in more detail the mechanisms of action between the effects of $\mathrm{Cr}$ and the functions of the respective genes. In our series, no single polymorphism was by itself altering the probability of lung cancer occurrence (Supplementary Material Table 5).

The data concerning sub-groups of particular genotypes were achieved on smaller number of patients and should be taken with special caution. Further investigations validating our results are required on larger groups of patients from different geographic regions and ethnic groups.

Another limitation of our study is that, the high risk of lung cancer is generally recognized as being associated with occupational exposure to $\mathrm{Cr}(\mathrm{VI})$, but we did not have patient work histories available to include in this study. Nevertheless, our study may provide an avenue to begin to screen for lung cancer occurrence, which is based on the large sample size and analyses focused on the general population.

\section{Conclusion}

In summary, our research provides evidence to connect $\mathrm{Cr}$ exposure to an increased incidence of lung cancers. However, these findings require the support by future studies that are capable of addressing the problem of other potential confounders in the association between exposure to $\mathrm{Cr}(\mathrm{VI})$ and lung cancer in the general population. At this time, we suggest that analysis of serum total chromium after further

Table 6 Genotypes and quartiles of Cr level with the highest/lowest frequency of lung cancer *

\begin{tabular}{lllll}
\hline DNA variant & Cr level $(\mu \mathrm{g} / \mathrm{L})$-quartile IV & $\begin{array}{l}\text { Quartile IV-cases/controls vs. } \\
\text { reference quartile-cases/controls }\end{array}$ & OR $(95 \%$ CI) \\
\hline ERCC2-rs13181 TT & $>0.12$ & $11 / 4$ & $5 / 8$ & $12.34(1.17-130.01)$ \\
CRTC3-rs12915189 nonGG & $>0.14$ & $18 / 9$ & $6 / 13$ & 9.04 \\
GSTP1-rs1695 nonAA & $>0.15$ & $21 / 14$ & $9 / 22$ & 9.01 \\
CAT-rs1001179 nonCC & $>0.15$ & $16 / 8$ & $5 / 16$ & $9.47(2.06-43.49)$ \\
\hline
\end{tabular}

* Statistical analyses on sub-groups of pairs matched also for genotypes

Italics - Results with statistical significance 
investigations on the medical and cost-effectiveness of this approach, might be useful in the effective detection of early lung cancers, especially in individuals with special genotypes.

Acknowledgments We thank Renata Gibaszek for her support in this study.

Funding Information The study was funded by the National Centre for Research and Development project PBS3/B7/26/2015.

\section{Compliance with Ethical Standards}

The study was conducted in accordance with the Helsinki Declaration and with the consent of the Ethics Committee of Pomeranian Medical University in Szczecin under the number KB-0012/73/10.

Conflict of Interest Jan Lubiński is the CEO of Read-Gene SA. These authors are part-time employees of Read-Gene: WM, RD, JG, TH, CC. The other authors declare that they have no conflict of interest.

Open Access This article is licensed under a Creative Commons Attribution 4.0 International License, which permits use, sharing, adaptation, distribution and reproduction in any medium or format, as long as you give appropriate credit to the original author(s) and the source, provide a link to the Creative Commons licence, and indicate if changes were made. The images or other third party material in this article are included in the article's Creative Commons licence, unless indicated otherwise in a credit line to the material. If material is not included in the article's Creative Commons licence and your intended use is not permitted by statutory regulation or exceeds the permitted use, you will need to obtain permission directly from the copyright holder. To view a copy of this licence, visit http://creativecommons.org/licenses/by/4.0/.

\section{References}

1. Ferlay J, Parkin DM, Steliarova-Foucher E (2010) Estimates of cancer incidence and mortality in Europe in 2008. Eur J Cancer 46:765-781. https://doi.org/10.1016/j.ejca.2009.12.014

2. National Lung Screening Trial Research Team, Aberle DR, Adams AM, Berg CD, Black WC, Clapp JD, Fagerstrom RM, Gareen IF, Gatsonis C, Marcus PM, Sicks JD (2011) Reduced lung-cancer mortality with low-dose computed tomographic screening. N Engl J Med 365(5):395-409. https://doi.org/10.1056/NEJMoa1 102873

3. Infante M, Cavuto S, Lutman FR, Passera E, Chiarenza M, Chiesa G, Brambilla G, Angeli E, Aranzulla G, Chiti A, Scorsetti M, Navarria P, Cavina R, Ciccarelli M, Roncalli M, Destro A, Bottoni E, Voulaz E, Errico V, Ferraroli G, Finocchiaro G, Toschi L, Santoro A, Alloisio M, DANTE Study Group (2015) Long-term follow-up results of theDANTE trial, a randomized study of lung cancer screening with spiral computed tomography. Am J Respir Crit Care Med 191:1166-1175. https://doi.org/10. 1164/rccm.201408-1475OC

4. Heuvelmans MA, Walter JE, Peters RB, Bock GH, Yousaf-Khan U, Aalst CMV, Groen HJM, Nackaerts K, Ooijen PMV, Koning HJ, Oudkerk M, Vliegenthart R (2017) Relationship between nodule count and lung cancer probability in baseline CT lung cancer screening: the NELSON study. Lung Cancer 113:45-50. https:// doi.org/10.1016/j.lungcan.2017.08.023
5. Hofman P (2017) Liquid biopsy for early detection of lung cancer. Curr Opin Oncol 29(1):73-78. https://doi.org/10.1097/CCO. 0000000000000343

6. Santarpia M, Liguori A, D'Aveni A, Karachaliou N, Gonzalez-Cao M, Daffinà MG, Lazzari C, Altavilla G, Rosell R (2018) Liquid biopsy for lung cancer early detection. J Thorac Dis 10(Suppl 7): S882-S897. https://doi.org/10.21037/jtd.2018.03.81

7. Boyle P, Chapman CJ, Holdenrieder S, Murray A, Robertson C, Wood WC, Maddison P, Healey G, Fairley GH, Barnes AC, Robertson JF (2011) Clinical validation of an autoantibody test for lung cancer. Ann Oncol 22(2):383-389. https://doi.org/10. 1093/annonc/mdq361

8. Ahrendt SA, Chow JT, Xu LH, Yang SC, Eisenberger CF, Esteller M, Herman JG, Wu L, Decker PA, Jen J, Sidransky D (1999) Molecular detection of tumor cells in bronchoalveolar lavage fluid from patients with early stage lung cancer. J Natl Cancer Inst 91(4): 332-339. https://doi.org/10.1093/jnci/91.4.332

9. Belinsky SA, Liechty KC, Gentry FD, Wolf HJ, Rogers J, Vu K, Haney J, Kennedy TC, Hirsch FR, Miller Y, Franklin WA, Herman JG, Baylin SB, Bunn PA, Byers T (2006) Promoter hypermethylation of multiple genes in sputum precedes lung cancer incidence in a high-risk cohort. Cancer Res 66(6):3338-3344. https://doi.org/10. 1158/0008-5472.CAN-05-3408

10. Zhang Y, Wang R, Song H, Huang G, Yi J, Zheng Y, Wang J, Chen L (2011) Methylation of multiple genes as a candidate biomarker in non-small cell lung cancer. Cancer Lett 303:21-28. https://doi.org/ 10.1016/j.canlet.2010.12.011

11. Wogan GN, Hecht SS, Felton JS, Conney AH, Loeb LA (2004) Environmental and chemical carcinogenesis. Semin Cancer Biol 14(6):473-486. https://doi.org/10.1016/j.semcancer.2004.06.010

12. Williams GM (2001) Mechanisms of chemical carcinogenesis and application to human cancer risk assessment. Toxicology 166(1-2): 3-10. https://doi.org/10.1016/s0300-483x(01)00442-5

13. Lee JC, Son YO, Pratheeshkumar P, Shi X (2012) Oxidative stress and metal carcinogenesis. Free Radic Biol Med 53(4):742-757. https://doi.org/10.1016/j.freeradbiomed.2012.06.002

14. De Matteis S, Consonni D, Lubin JH, Tucker M, Peters S, Vermeulen R, Kromhout H, Bertazzi PA, Caporaso NE, Pesatori A, Wacholder S, Landi MT (2012) Impact of occupational carcinogens on lung cancer risk in a general population. Int J Epidemiol 41(3):711-721. https://doi.org/10.1093/ije/dys042

15. Costa M, Klein CB (2006) Toxicity and carcinogenicity of chromium compounds in humans. Crit Rev Toxicol 36(2):155-163. https://doi.org/10.1080/10408440500534032

16. Vincent JB (2000) The biochemistry of chromium. J Nutr 130(4): 715-718. https://doi.org/10.1093/jn/130.4.715

17. Cefalu WT, Hu FB (2004) Role of chromium in human health and in diabetes. Diabetes Care 27(11):2741-2751. https://doi.org/10. 2337/diacare.27.11.2741

18. Bagchi D, Stohs SJ, Downs BW, Bagchi M, Preuss HG (2002) Cytotoxicity and oxidative mechanisms of different forms of chromium. Toxicol 180(1):5-22. https://doi.org/10.1016/s0300$483 \mathrm{x}(02) 00378-5$

19. Nickens KP, Patierno SR (2010) Ceryak S (2010) chromium genotoxicity: a double-edged sword. Chem Biol Interact 188: 276-288. https://doi.org/10.1016/j.cbi.2010.04.018

20. Shi XL, Dalal NS (1989) Chromium (V) and hydroxyl radical formation during the glutathione reductase-catalyzed reduction of chromium (VI). Biochem Biophys Res Commun 163(1):627-634. https://doi.org/10.1016/0006-291x(89)92183-9

21. Jones P, Kortenkamp A, O'Brien P, Wang G, Yang G (1991) Evidence for the generation of hydroxyl radicals from a chromium(V) intermediate isolated from the reaction of chromate with glutathione. Arch Biochem Biophys 286(2):652-655. https:// doi.org/10.1016/0003-9861(91)90095-Z 
22. Itoh M, Nakamura M, Suzuki T, Kawai K, Horitsu H, Takamizawa K (1995) Mechanism of chromium(VI) toxicity in Escherichia coli: is hydrogen peroxide essential in $\mathrm{Cr}(\mathrm{VI})$ toxicity? J Biochem 117(4):780-786. https://doi.org/10.1093/oxfordjournals.jbchem. a124776

23. Stearns DM, Kennedy LJ, Courtney KD, Giangrande PH, Phieffer LS, Wetterhahn KE (1995) Reduction of chromium(VI) by ascorbate leads to chromium-DNA binding and DNA strand breaks in vitro. Biochemistr 34(3):910-919. https://doi.org/10.1021/ bi00003a025

24. Stearns DM, Wetterhahn KE (1994) Reaction of chromium(VI) with ascorbate produces chromium(V), chromium(IV), and carbon-based radicals. Chem Res Toxicol 7(2):219-230. https:// doi.org/10.1021/tx00038a016

25. Jennette KW (1982) Microsomal reduction of the carcinogen chromate produces chromium (V). J AmChem Soc 104:874-875

26. Asatiani N, Sapojnikova N, Abuladze M, Kartvelishvili T, Kulikova N, Kiziria E, Namchevadze E, Holman HY (2004) Effects of $\mathrm{Cr}(\mathrm{VI})$ long-term and low-dose action on mammalian antioxidant enzymes(an in vitro study). J Inorg Biochem 98:490496. https://doi.org/10.1016/j.jinorgbio.2003.12.014

27. Ceryak S, Zingariello C, O'Brien T, Patierno SR (2004) Induction of pro-apoptotic and cell cycle-inhibiting genes in chromium (VI)treated human lung fibroblasts: lack of effect of ERK. Mol Cell Biochem 255:139-149. https://doi.org/10.1023/b:mcbi. $0000007270.82431 .3 \mathrm{e}$

28. Salnikow K, Zhitkovich A (2008) Genetic and epigenetic mechanisms in metal carcinogenesis and cocarcinogenesis: nickel, arsenic, and chromium. Chem Res Toxicol 21:28-44. https://doi.org/ 10.1021/tx700198a

29. O'Brien TJ, Witcher P, Brooks B, Patierno SR (2009) DNA polymerase zeta is essential for hexavalent chromium-induced mutagenesis. Mutat Res 663:77-83. https://doi.org/10.1016/j.mrfmmm. 2009.01.012

30. Reynolds M, Peterson E, Quievryn G, Zhitkovich A (2004) Human nucleotide excision repair efficientlyremoves chromium-DNA phosphate adducts and protects cells against chromate toxicity. J Biol Chem 279:30419-30424. https://doi.org/10.1074/jbc. M402486200

31. Brooks B, O'Brien TJ, Ceryak S, Wise SJP, Wise SS, Wise JP Jr, Defabo E, Patierno SR (2008) Excision repair is required for genotoxin-induced mutagenesis in mammalian cells. Carcinogenesis 29:1064-1069. https://doi.org/10.1093/carcin/ bgn058

32. Holmes AL, Wise SS, Wise SJP (2008) Carcinogenicity of hexavalent chromium. Indian J Med Res 128:353-372

33. Takahashi Y, Kondo K, Hirose T, Nakagawa H, Tsuyuguchi M, Hashimoto M, Sano T, Ochiai A, Monden Y (2005) Microsatellite instability and protein expression of the DNA mismatch repair gene,hMLH1, of lung cancer in chromate-exposed workers. Mol Carcinog 42:150-158. https://doi.org/10.1002/mc.20073

34. Kondo K, Takahashi Y, Hirose Y, Nagao T, Tsuyuguchi M, Hashimoto M, Ochiai A, Monden Y, Tangoku A (2006) The reduced expression and aberrant methylation of p16(INK4a) in chromate workers with lung cancer. Lung Cancer 53:295-302. https:// doi.org/10.1016/j.lungcan.2006.05.022

35. Sun H, Zhou X, Chen H, Li Q, Costa M (2009) Modulation of histone methylation and MLH1 genesilencing by hexavalent chromium. Toxicol Appl Pharmacol 237:258-266. https://doi.org/10. 1016/j.taap.2009.04.008

36. Daniels CE, Jett JR (2005) Does interstitial lung disease predispose to lung cancer? Curr Opin Pulm Med 11:431-437. https://doi.org/ 10.1097/01.mcp.0000170521.71497.ba

37. Solano-Lopez C, Zeidler-Erdely PC, Hubbs AF, Reynolds SH, Roberts JR, Taylor MD, Young SH, Castranova V, Antonini JM (2006) Welding fume exposure and associated inflammatory andhyperplastic changes in the lungs of tumor susceptible $\mathrm{a} / \mathrm{j}$ mice. Toxicol Pathol 34:364-372. https://doi.org/10.1080/ 01926230600815122

38. Wise SS, Holmes AL, Wise SJP (2006) Particulate and soluble hexavalent chromium are cytotoxic and genotoxic to human lung epithelial cells. Mutat Res 610:2-7. https://doi.org/10.1016/j. mrgentox.2006.06.005

39. Patierno SR, Banh D, Landolph JR (1988) Transformation of C3H/ $10 \mathrm{~T} 1 / 2$ mouse embryo cells to focusformation and anchorage independence by insoluble lead chromate but not soluble calciumchromate: relationship to mutagenesis and internalization of lead chromate particles. Cancer Res 48:5280-5288

40. Léonard A, Lauwerys RR (1980) Carcinogenicity and mutagenicity of chromium. Mutat Res 76:227-239. https://doi.org/10.1016/ 0165-1110(80)90018-4

41. Levy LS, Venitt S (1986) Carcinogenicity and mutagenicity of chromium compounds: the associationbetween bronchial metaplasia and neoplasia. Carcinogenesis 7:831-835. https://doi.org/10. 1093/carcin/7.5.831

42. Kondo K, Hino N, Sasa M, Kamamura Y, Sakiyama S, Tsuyuguchi M, Hashimoto M, Uyama T, Monden Y (1997) Mutations of the p53 gene in human lung cancer from chromate-exposed workers. Biochem Biophys Res Commun 239:95-100. https://doi.org/10. 1006/bbrc.1997.7425

43. Kiyohara C, Horiuchi T, Takayama K, Nakanishi Y (2012) Genetic polymorphisms involved in carcinogen metabolism and DNA repair and lung cancer risk in a Japanese population. J Thorac Oncol 7(6):954-962. https://doi.org/10.1097/JTO.0b013e31824de30f

44. Jafari Nedooshan J, Forat Yazdi M, Neamatzadeh H, Zare Shehneh M, Kargar S, Seddighi N (2017) Genetic association of XRCC1 gene rs 1799782, rs25487 and rs25489 polymorphisms with risk of thyroid cancer: a systematic review and meta-analysis. Asian Pac J Cancer Prev 18(1):263-270. https://doi.org/10.22034/ APJCP.2017.18.1.263

45. Zavras AI, Yoon AJ, Chen MK, Lin CW, Yang SF (2011) Metallothionein-1 genotypes in the risk of oral squamous cell carcinoma. Ann Surg Oncol 18(5):1478-1483. https://doi.org/10. 1245/s10434-010-1431-3

46. Ritchie KJ, Henderson CJ, Wang XJ, Vassieva O, Carrie D, Farmer PB, Gaskell M, Park K, Wolf CR (2007) Glutathione transferase pi plays a critical role in the development of lung carcinogenesis following exposure to tobacco-related carcinogens and urethane. Cancer Res 67(19):9248-9257. https://doi.org/10.1158/00085472.CAN-07-1764

47. Kudhair BK, Alabid NN, Taheri-Kafrani A, Lafta IJ (2020) Correlation of GSTP1 gene variants of male Iraqi waterpipe (Hookah) tobacco smokers and the risk of lung cancer. Mol Biol Rep 47(4):2677-2684. https://doi.org/10.1007/s11033-020-05359$\mathrm{w}$

48. Llop S, Engstrom K, Ballester F, Franforte E, Alhamdow A, Pisa F, Tratnik JS, Mazej D, Murcia M, Rebagliato M, Bustamante M, Sunyer J, Sofianou-Katsoulis A, Prasouli A, Antonopoulou E, Antoniadou I, Nakou S, Barbone F, Horvat M, Broberg K (2014) Polymorphisms in $\mathrm{ABC}$ transporter genes and concentrations of mercury in newborns-evidence from two Mediterranean birth cohorts. PLoS One 9(5):e97172. https://doi.org/10.1371/journal.pone. 0097172

49. Jaiswal AK, McBride OW, Adesnik M, Nebert DW (1988) Human dioxin-inducible cytosolic NAD $(\mathrm{P}) \mathrm{H}$ :menadione oxidoreductase. cDNA sequence and localization of gene to chromosome 16. J Biol Chem 263:13572-13578

50. Huang J, Lin H, Wu X, Jin W, Zhang Z (2017) NQO1 C609T polymorphism and lung cancer susceptibility: evidence from a comprehensive meta-analysis. Oncotarget 8(60):102301-102309. https://doi.org/10.18632/oncotarget.21084 
51. Birkeland AC, Foltin SK, Michmerhuizen NL, Hoesli RC, Rosko AJ, Byrd S, Yanik M, Nor JE, Bradford CR, Prince ME, Carey TE, McHugh JB, Spector ME, Brenner JC (2017) Correlation of CRTC1/3-MAML2 fusion status, grade and survival in mucoepidermoid carcinoma. Oral Oncol 68:5-8. https://doi.org/ 10.1016/j.oraloncology.2017.02.025

52. Luciano M, Hansell NK, Lahti J, Davies G, Medland SE, Raikkonen K, Tenesa A, Widen E, McGhee KA, Palotie A, Liewald D, Porteous DJ, Starr JM, Montgomery GW, Martin NG, Eriksson JG, Wright MJ, Deary IJ (2011) Whole genome association scan for genetic polymorphisms influencing information processing speed. Biol Psychol 86(3):193-202. https://doi.org/ 10.1016/j.biopsycho.2010.11.008

53. $\mathrm{Ng}$ E, Lind PM, Lindgren C, Ingelsson E, Mahajan A, Morris A, Lind L (2015) Genome-wide association study of toxic metals and trace elements reveals novel associations. Hum Mol Genet 24(16): 4739-4745. https://doi.org/10.1093/hmg/ddv190

54. Raaschou-Nielsen O, Sørensen M, Hansen RD, Frederiksen K, Tjønneland A, Overvad K, Vogel U (2007) GPX1 Pro198Leu polymorphism, interactions with smoking and alcohol consumption, and risk for lung cancer. Cancer Lett 247(2):293-300. https://doi. org/10.1016/j.canlet.2006.05.006

55. Ratnasinghe D, Tangrea JA, Andersen MR, Barrett MJ, Virtamo J, Taylor PR, Albanes D (2000) Glutathione peroxidase codon 198 polymorphism variant increases lung cancer risk. Cancer Res 60(22):6381-6383

56. Li N, Huang HQ, Zhang GS (2014) Association between SOD2 C47T polymorphism and lung cancer susceptibility: a meta-analysis. Tumour Biol 35(2):955-959. https://doi.org/10.1007/s13277013-1127-y
57. Chung-man Ho J, Zheng S, Comhair SA, Farver C, Erzurum SC (2001) Differential expression of manganese superoxide dismutase and catalase in lung cancer. Cancer Res 61(23):8578-8585

58. Shen Y, Li D, Tian P, Shen K, Zhu J, Feng M, Wan C, Yang T, Chen L, Wen F (2015) The catalase C-262T gene polymorphism and cancer risk: a systematic review and meta-analysis. Medicine (Baltimore) 94(13):e679. https://doi.org/10.1097/MD. 0000000000000679

59. Lahiri DK, Schnabel B (1993) DNA isolation by rapid method from human blood samples: effects of $\mathrm{MgCl}_{2}$, EDTA, storage time, and temperature on DNA yield and quality. Biochem Genet 31:321328. https://doi.org/10.1007/bf02401826

60. Yang D, Liu Y, Bai C, Wang X, Powell CA (2020) Epidemiology of lung cancer and lung cancer screening programs in China and the United States. Cancer Lett 468:82-87. https://doi.org/10.1016/j. canlet.2019.10.009

61. Cherrie JW, Hutchings S, Gorman NM, Mistry R, Corden C, Lamb J, Sanchez Jimenez A, Shafrir A, Sobey M, van Tongeren M, Rushton L (2017) Prioritising action on occupational carcinogens in Europe: a socioeconomic and health impact assessment. Br J Cancer 117(2):274-281. https://doi.org/10.1038/bjc.2017.161

62. ATSDR (2020) ToxGuide ${ }^{\mathrm{TM}}$ for Chromium Cr Agency for Toxic Substances and Disease Registry http://www.atsdr.cdc.gov/ toxprofiles/index.asp. Accessed 24 February 2020

63. Pappas RS (2011) Toxic elements in tobacco and in cigarette smoke: inflammation and sensitization. Metallomics 3:11811198. https://doi.org/10.1039/c1mt00066g

Publisher's Note Springer Nature remains neutral with regard to jurisdictional claims in published maps and institutional affiliations. 